Conference Proceedings

Journal of Technology in Counselor Education and Supervision (ISSN 2692-4192)

Volume 1(1): 39 - 41

(c) 2021Journal of Technology in Counselor Education and Supervision https://doi.org/10.22371/tces/006

\title{
The Past, Present and Future of Online Counselor Education
}

\author{
Kelly Coker ${ }^{1}$, William Snow ${ }^{2}$, \& Scott Hinkle ${ }^{3}$
}

\begin{abstract}
COVID-19 accelerated the adoption of distance learning in 2020 throughout the world. Online education is now central to counselor education and the trend will likely continue post COVID-19 as well. The history of distance education technology in counselor education is first explored and then the advantages and challenges of this learning model are discussed along with the ethical, legal and regulatory implications. Finally, the future of counselor education is explored along with emerging technologies that may again disrupt our teaching and learning models.
\end{abstract}

\section{Keywords}

research, counseling, pedagogy, counselor education, research identity

Historically, learning technologies have moved from the written word to the printing press, to sound recordings and film, to radio, television, and telephone, to computers and the internet. In the current digital age, counselor education programs are proliferating and much of the current focus is on ways to reduce the distance in distance education. This has led to discussions on who can best can succeed in a distance learning environment (Shearer, 2003. It is now widely held that self-regulated learners who take responsibility for their education tend to persist and graduate (Snow \& Coker, 2020).

The Council for Accreditation of Counseling and Related Education Programs (CACREP, 2015) does not dictate the manner in which a counselor education graduate program meets accreditation standards. Distance education is an acceptable and innovative way to educate counselors, as long as the online student meets the same training and educational standards as their residential counterpart.

Advantages of Counselor Education Distance Learning

Online counselor education provides opportunities for students from diverse backgrounds who typically have few alternatives to extend their learning (Snow \& Coker, 2020). Adult learners who work fulltime, have families and childcare responsibilities, are

\begin{tabular}{ll}
\hline 1 & Palo Alto University, Palo Alto, CA, USA \\
2 & Palo Alto University, Palo Alto, CA, USA \\
3 & Palo Alto University, Palo Alto, CA, USA
\end{tabular} geographically isolated, and mobility-challenged may choose online learning options that fit their circumstances as well as their learning style (Snow et al., 2018). Distance counselor education also provides opportunities for international students (Ju et al., 2016).

\section{Challenges of Counselor Education Distance Learning}

Students engaged in online counselor education want to feel more connected to their university. Faculty teaching styles need to be better adapted to distance learning formats. Thorough screening at admissions for compatibility to online education, student access to technology, and university learning platform support all need to be continually assessed. Students living away from the physical campus will require regular practicum and internship support which can be a challenge at a distance (Snow et al., 2018).

Counselor education faculty in distance education programs face unique gatekeeping responsibilities. Students can find a way to "hide" behind discussion board posts and other assignments in a manner that keeps professors from ascertaining problematic student biases, opinions, and personality traits that would be typically picked up in face-to-face instruction

Corresponding Author: Kelly Coker, PhD, Palo Alto University, 1791 Arastradero Road, Palo Alto, CA 94304 email:kcoker@paloaltou.edu 
Monitoring student's professional behavior and clinical skills at a distance can be a challenge when perceived anonymity is a potential issue (Freeman \& Bamford, 2004; McAdams \& Wyatt, 2010; Vaccaro \& Lambie, 2007).

\section{Ethical, Legal, and Regulatory Implications}

Other considerations for counselor educators working in distance education deliveries include security, privacy, and access (Snow \& Coker, 2020). Whether working in distance education, brick and mortar or a hybrid model, counselor educators must adhere to the American Counseling Association (ACA) Code of Ethics (2014). Section F of the ACA Code of Ethics speaks to trainers, teachers, and supervisors' responsibility in adhering to professional roles and boundaries and in being fair and honest in the assessment of counselors in training (ACA, 2014). Only one code in this section (F.2.c.) references training at a distance and the importance of competently using technologies and safeguarding confidentiality in the process. According to Sheperis et al. (2020), the use of technologies such as video conferencing software can create difficult situations related to student privacy and client confidentiality. Counselor educators should be mindful of the types of platforms used and whether they offer end-toend encryption, firewall protections, and possibly even Business Associates Agreements (BAA's) to validate the privacy offered (Sheperis et al., 2020).

The shift to online education opens up the possibility of serving a wider student population across state lines and even internationally. There are legal and licensure implications of working with students across borders. Counselor education programs and faculty have the responsibility to provide students with information about educational requirements for licensure in their respective states and countries, and to keep abreast of changing licensure laws and regulations, This is no small feat; especially for programs and universities that may not be adequately resourced to systematically track the ever-changing landscape of state regulations and licensure laws.

As supervisors and gatekeepers, counselor educators working with students in online and distance education platforms also need to consider their ability to gauge student knowledge, skill, and dispositions development. While advances in technology have afforded distance education programs to create robust deliveries of counselor education, it is imperative that platforms used promote opportunities for counselor educators and supervisors to observe both professional dispositions and behaviors and clinical skills. Some distance counselor education programs include residency requirements where students travel to a location to participate in face-to-face learning, but increasingly distance education programs are relying on secure video conferencing (Zoom, Google Meet, Microsoft Teams) and synchronous opportunities to train students in clinical skills. As the world has been adjusting to the impact of the COVID-19 crisis, counseling programs have had to pivot to distance learning modalities to train counseling students, so it will be interesting to see the impact of this shift on future directions in counselor training.

\section{The Future of Counselor Education at a Distance}

In 2016, over six million students in the U.S. were engaged in distance education and nearly half were exclusively taking online classes (Seaman, Allen, \& Seaman, 2018). In 2020 the Council for the Accreditation of Counseling and Related Educational Programs (CACREP) reported that there were sixty-nine accredited master's programs that were considered distance education, thirty-four of which are clinical mental health counseling (CACREP, n.d.).

In the last year, COVID-19 accelerated the growth of online learning. Much of the world from ages 8 to 80 became experienced in meeting and learning via the internet. Individuals engaged in counseling and psychotherapy found themselves shifting to a telemedicine approach to treatment. A good indication of this acceleration is the growth of Zoom teleconference usage. In December 2019 the peak Zoom daily usage was about 10 million. That grew to 300 million by April of 2020. (Zoom Revenue and Usage Statistics, 2020). By January of 2021 Zoom reported an average of 350 million daily users (What's Next for Zoom in 2021?, 2021). For much of 2020 , most of the world's colleges and universities, including counseling programs, were instructing via online platforms - this trend will continue in 2021.

2020's abrupt move to online will have impacts for years to come. The COVID-19 generation of counseling students will no longer see online learning as a novelty. Many students who would never have considered online counselor education or telemedicine will have found these modes acceptable. Student experiences with remote learning and virtual mental health counseling will become critical skillsets for the future of counseling in the 21st century (Snow \& Coker, 2020).

Emerging technologies will bring new possibilities for those that can harness their potential. One of those technologies is the use of avatars powered by increasingly sophisticated artificial intelligence (AI). This technology is being used to make phone calls and interact with people for commercial purposes. It is only a matter of time until avatars are used to assist in counselor 
training (Riva \& Vincelli, 2001). Eventually we may find low-cost therapy for the masses through this emerging medium.

Virtual Reality (VR) is another technology with teaching and therapeutic possibilities. Virtual reality can create a heightened sense of reality that far surpasses what we now experience in role plays, demonstrations and via teleconference. The costs are coming down and the available software is growing. It is a matter of time before VR classrooms and therapy sessions are now as prevalent as Zoom sessions are today.

\section{Conclusion}

Although distance counselor education is here to stay and no longer on the margins of the educational system, more work needs to be done to instill the belief that quality outcomes can be achieved with online counselor education programs (Snow et al., 2016. Snow et al (2018) have reported that, "There is a lingering perception...that online counselor education programs are not equivalent to residential training" ( $p$. 142). To address such perceptions, research is needed in program development that utilizes various technologies, distance learning outcomes as compared to faceto-face instruction, and contrasts and similarities in the demonstration of actual counseling skills among online graduates compared to traditional education.

Best practices in counselor education will only improve as research data informs policies and pedagogy (Snow et al., 2016), and learning outcomes are judged by their merit, not by their mode of delivery (Lezberg, 2003).

\section{References}

American Counseling Association. (2014). ACA code of ethics.https://www.counseling.org/Resources/aca-code-ofethics.pdf

Council for Accreditation of Counseling and Related Educational Programs. (2015). 2016 CACREP standards. Retrieved from: https://www.cacrep.org/ for-programs/2016-cacrep-standards/

Council for Accreditation of Counseling and Related Educational Programs. (2017). Annual report 2016. Washington, DC: Author.

Council for the Accreditation of Counseling and Related Educational Programs. (n.d.). Directory of accredited programs. https://cacrep.org/directory

Freeman, M., \& Bamford, A. (2004). Student choice of anonymity for learner identity in online learning discussion forums. International Journal of ELearning. Retrieved from http://highbeam.com/doc/1G1-121573154.html

Ju, J., Snow, W. H., \& Hinkle, J. S. (2016, October). Development of a counseling program for an international cohort. Program presented at the Western Association for
Counselor Education and Supervision Conference, Vancouver, BC.

Lezberg, A. K. (2003). Accreditation: Quality control in higher distance education. In M. G Moore \& W. G. Anderson (Eds.), Handbook of distance education (pp. 425-434). Mahwah, NJ: Lawrence Erlbaum.

McAdams, III, C. R., \& Wyatt, K. L. (2010). The regulation of technology-assisted distance counseling and supervision in the United States: An analysis of current extent, trends, and limitations. Counselor Education \& Supervision, 49, 179-192.

Riva, G., \& Vincelli, F. (2001). Virtual reality as an advanced imaginal system: A new experiential approach for counseling and therapy. International Journal of Action Methods, 54(2), 51-64.

Seaman, J. E., Allen, I. E., \& Seaman, J. (2018). Grade increase: Tracking distance education in the United States. Babson Survey Research Group. https://onlinelearningsurvey.com/reports/gradeincrease.pdf

Shearer, R. (2003). Instructional design in distance education: An overview. In M. G Moore \& W. G. Anderson (Eds.), Handbook of distance education (pp. 275-286). Mahwah, NJ: Lawrence Erlbaum.

Sheperis, D. S., Ordway, A., \& Lamar, M. (2020). Legal and ethical challenges in online counselor education. The Professional Counselor, 10(1), 106-119. doi:10.15241/ dss.10.1.106

Snow, W. H., \& Coker, J. K. (2020). Distance counselor education: Past, present, future. The Professional Counselor, 10, 40-56. doi:10.15241/whs.10.1.40

Snow, W. H., Lamar, M. R., Hinkle, J. S., \& Speciale, M. (2018). Current practices in online counselor education. The Professional Counselor, 8, 131-145. doi:10.15241/ whs.8.2.131

Snow, W. H., Hinkle, J. S., Lamar, M., Speciale, M., \& Baima, T. (2016, April). Current and future directions: The virtual remote online counselor education classroom. Presentation at the American Counseling Association Conference and Expo, Montreal, Canada.

Snow, W. H., Hinkle, J. S., Lamar, M. R., Speciale, M., \& Baima, T., Roller, K., \& Ju, J. (2016, October). Best practices in online counselor education. Program presented at the Western Association for Counselor Education and Supervision Conference, Vancouver, BC.

Vaccaro, N., \& Lambie, G. W. (2007). Computer-based counselor-in-training supervision: Ethical and practical implications for counselor educators and supervisors. Counselor Education \& Supervision, 47, 46-57.

What's Next for Zoom in 2021? (2021, January 12). UC Today. https://www.uctoday.com/collaboration/ video-conferencing/whats-next-for-zoom-in-2021/

Zoom Revenue and Usage Statistics (2020). Business of Apps. https://www.businessofapps.com/data/ zoom-statistics/ 